\title{
Artikel Review
}

\section{Pengetahuan, Sikap, dan Praktik Tenaga Kesehatan terhadap Penyakit Tuberkulosis: Sebuah Review}

\author{
Idzni R. E. Yahya ${ }^{1}$, Rano K. Sinuraya ${ }^{1,2}$, Irma M. Puspitasari ${ }^{1,2}$ \\ ${ }^{1}$ Departemen Farmakologi dan Farmasi Klinik, Fakultas Farmasi, Universitas Padjadjaran, \\ Sumedang, Indonesia, ${ }^{2}$ Pusat Unggulan Iptek (PUI) Perguruan Tinggi Inovasi Pelayanan \\ Kefarmasian, Universitas Padjadjaran, Bandung, Indonesia
}

\begin{abstract}
Abstrak
Tuberkulosis (TB) merupakan salah satu penyakit infeksi yang menempati urutan ke-10 penyebab kematian tertinggi di dunia. Pada tahun 2018, diperkirakan 1,3 juta orang meninggal akibat penyakit TB. Tenaga kesehatan merupakan salah satu pekerjaan yang memiliki risiko besar terkena TB. Artikel ini menilai pengetahuan, sikap dan praktik (KAP) tenaga kesehatan terhadap TB. Studi observasional dicari di database elektronik PubMed pada April 2020. Tujuh belas studi diidentifikasi dari 100 studi yang ditemukan, dengan waktu publikasi lima tahun terakhir. Studi dilakukan di seluruh dunia termasuk di negara Asia, Afrika, Eropa dan Amerika. Studi ini menunjukkan bahwa tenaga kesehatan dalam 9 dari 16 penelitian memiliki tingkat pengetahuan yang buruk, memiliki sikap negatif dalam 6 dari 13 penelitian, dan praktik yang buruk dalam 6 dari 11 penelitian. Hasil tersebut secara keseluruhan dinilai masih kurang baik dan terdapat beberapa kesenjangan dalam pencegahan dan pengendalian infeksi TB. Pengetahuan, sikap, dan praktik tenaga kesehatan dapat ditingkatkan dengan peningkatan pengetahuan dan pelatihan pengendalian infeksi TB.
\end{abstract}

Kata kunci: Infeksi, pengetahuan, praktik, sikap, tenaga kesehatan, tuberkulosis

\section{Knowledge, Attitudes, and Practices of Healthcare Professional towards Tuberculosis: A Review}

\begin{abstract}
Tuberculosis (TB) is an infectious disease and one of the top 10 causes of death worldwide. In 2018, it was estimated that 1.3 million people would die from TB. However, healthcare worker is a profession with high risk of TB infection. Therefore, this review aims to assess the knowledge, attitudes, and practices (KAP) of healthcare professionals towards TB. This observational studies were sought from PubMed database in April 2020. Then, seventeen studies were identified from 100 published articles in the last five years. This review involved the studies all over the world including Asian, African, European, and American. Nine of the 16 studies showed that healthcare professionals had poor levels of knowledge, while in 6 of 13 they had negative attitudes, and in 6 of 11 they had poor practice. Also, it was observed that knowledge, attitudes, and practice of the healthcare professional are still poor towards TB, and there were some differences between its infection, prevention and control. Therefore, these features (KAP) need improvement through critical training on tuberculosis.
\end{abstract}

Keywords: Attitudes, healthcare professional, infection, knowledge, practice, tuberculosis

Korespondensi: Idzni R. E. Yahya, S.Farm., Fakultas Farmasi, Universitas Padjadjaran, Sumedang, Jawa Barat 45363.Indonesia, email: idzni16001@mail.unpad.ac.id

Naskah diterima: 7 Mei 2020, Diterima untuk diterbitkan: 30 Juni 2020, Diterbitkan: 29 September 2020 


\section{Pendahuluan}

Tuberkulosis (TB) merupakan sebuah masalah kesehatan masyarakat yang penting di dunia. TB menempati urutan ke-10 sebagai penyebab kematian tertinggi di dunia dengan angka kematian diperkirakan 1,3 juta pasien. ${ }^{1}$ Menurut World Health Organization (WHO), TB adalah penyakit infeksi yang disebabkan oleh Mycobacterium tuberculosis yang dapat menular melalui udara. Infeksi ini dapat memengaruhi paru-paru dan organ lainnya (TB luar paru). ${ }^{2}$ Tanda gejala dari TB berupa batuk berdahak selama dua minggu. Gejala tambahan lainnya seperti batuk darah, badan lemas, nafsu makan menurun, sesak nafas, berkeringat malam hari tanpa kegiatan fisik, serta demam yang lebih dari satu bulan. ${ }^{3}$

Secara global tahun 2018, diperkirakan 10 juta orang menderita penyakit TB, yaitu 1 setara dengan total 132 kasus per 100.000 populasi. Dari total kasus penyakit TB pada tahun 2018, sebagian besar terjadi di wilayah Asia Tenggara (44\%), wilayah Afrika (24\%) dan wilayah Pasifik Barat (18\%). Delapan negara menyumbang dua pertiga dari total kasus TB di dunia, yaitu India (27\%), Cina (9\%), Indonesia (8\%), Filipina (6\%), Pakistan (6\%), Nigeria (4\%), Bangladesh (4\%), dan Afrika Selatan (3\%). ${ }^{2}$

Risiko infeksi TB lebih besar terjadi pada petugas kesehatan dibanding populasi umum atau masyarakat. ${ }^{4}$ Petugas kesehatan terdiri dari dokter, baik dokter umum, spesialis, dan termasuk dokter kesehatan masyarakat, dokter gigi, perawat, bidan, farmasis, dan pekerja laboratorium. ${ }^{5,6}$ Petugas kesehatan di fasilitas yang mendiagnosis dan merawat pasien TB juga berisiko lebih tinggi. Selain itu, petugas kesehatan yang lebih sering kontak langsung dengan pasien, yang memiliki durasi kerja yang lebih lama, yang memiliki kontak dengan pasien TB yang belum didiagnosis dan terapi, dan yang melakukan prosedur menginduksi batuk pada pasien, berisiko lebih tinggi dalam penularan nosokomial. ${ }^{6}$ TB sebagai masalah kesehatan masyarakat global dibutuhkan pemahaman yang lebih baik. Selain itu, diperlukan pencegahan dan kontrol yang lebih baik terhadap penyakit tersebut melalui pengetahuan, sikap serta praktik yang baik mengenai TB. ${ }^{7}$ Oleh karena itu, artikel review ini memberikan gambaran bagaimana pengetahuan, sikap, dan praktik terhadap penyakit TB pada tenaga kesehatan untuk membantu pencegahan dan kontrol penyakit TB.

\section{Metode}

Pencarian literatur dengan waktu publikasi 5 tahun terakhir dilakukan pada basis data data elektronik PubMed pada bulan April 2020 menggunakan kata kunci "knowledge", "attitude", "practice", "healthcare worker", dan " tuberculosis". Detail pencarian adalah sebagai berikut: (((("knowledge"[MeSH Terms] OR "knowledge"[All Fields]) AND ("attitude" [MeSH Terms] OR "attitude"[All Fields]) AND ("Practice (Birm)"[Journal] OR "practice"[All Fields])) AND ("health personnel" [MeSH Terms] OR ("health"[All Fields] AND "personnel"[All Fields]) OR "health personnel"[All Fields] OR ("healthcare" [All Fields] AND "worker"[All Fields]) OR "healthcare worker"[All Fields])) AND ("tuberculosis"[MeSH Terms] OR "tuberculosis"[All Fields])) NOT ("review" [Publication Type] OR "review literature as topic"[MeSH Terms] OR "review"[All Fields]) AND ("2015/ 04/30" [PDat] : "2020/ 04/27"[PDat]).

Sebanyak 100 artikel diperoleh pada pencarian awal, kemudian diekstraksi dengan kriteria inklusi yaitu artikel merupakan studi kuantitatif yang menilai hasil pengetahuan, sikap, dan praktik dari subjek tenaga kesehatan baik penyedia layanan yang bekerja secara individual, pelayanan swasta atau dalam organisasi pemerintah, artikel dalam bahasa 
Inggris dan dipublikasi dalam kurun waktu 5 tahun terakhir.

\section{Hasil}

Diagram alir pencarian literatur ditunjukkan dalam Gambar 1. Pada pencarian literatur awal didapatkan 100 artikel penelitian, 83 di antaranya dieksklusi berdasarkan judul dan abstrak sebab tema literatur bukan mengenai TB dan KAP. Sebanyak 17 artikel memenuhi kriteria inklusi dan dapat dilihat pada Tabel 1. Artikel yang diperoleh terpublikasi dari Januari 2015 hingga Maret 2020. Penelitian dilakukan di benua Asia, Afrika, Eropa dan Amerika. Seluruh studi merupakan crosssectional study dan pemilihan sampel dengan random sampling atau purposive sampling. Ukuran sampel berkisar dari 44 hingga 1016 responden dengan total 5251 responden.
Sebanyak dua studi menggunakan instrumen survei yaitu kuesioner yang dikelola sendiri dan 15 studi menggunakan instrumen yang diadaptasi dan dikembangkan dari pedoman TB di negaranya, pedoman WHO, dan studi sebelumnya.

\section{Pengetahuan Tenaga Kesehatan terhadap TB}

Tabel 2 menggambarkan pengetahuan tenaga kesehatan terhadap TB. Secara keseluruhan, 7 dari 16 studi mengenai pengetahuan tenaga kesehatan menunjukkan hasil yang baik, namun beberapa negara seperti Norwegia, Cina, Iran, India, Meksiko, Brazil, Ethiopia, Afrika Selatan dan Indonesia masih memiliki pengetahuan yang kurang baik, dan negaranegara tersebut merupakan negara dengan beban TB tertinggi di dunia. ${ }^{2}$

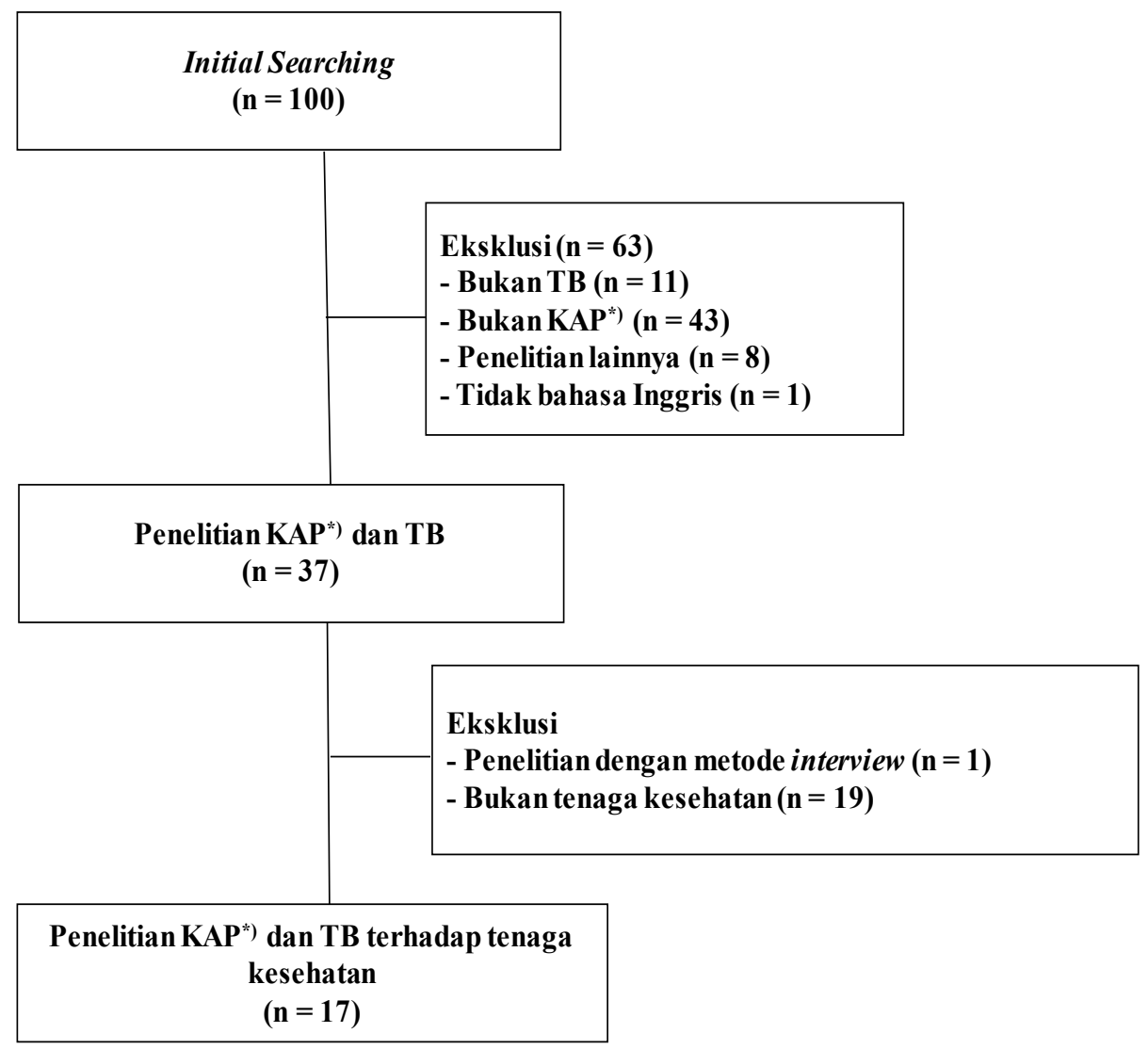

Gambar 1 Bagan Alir Pencarian Literatur

Keterangan: *KAP=Knowledge (pengetahuan), attitudes (sikap), practices (praktik) 


\begin{tabular}{|c|c|c|c|c|c|c|c|c|}
\hline $\begin{array}{c}\text { No. } \\
\text { Artikel }\end{array}$ & Penulis & $\begin{array}{l}\text { Tahun } \\
\text { Terbit }\end{array}$ & Lokasi Penelitian & Variabel & $\begin{array}{c}\text { Rancangan } \\
\text { Penelitian }\end{array}$ & Responden & $\begin{array}{c}\text { Jumlah } \\
\text { Responden }\end{array}$ & $\begin{array}{l}\text { Instrumen } \\
\text { Penelitian }\end{array}$ \\
\hline 1 & Irani et al. ${ }^{23}$ & 2015 & Iran & KAP & Cross-sectional study & $\begin{array}{l}\text { Staf Laboratorium } \\
\text { TB } \\
\text { Staf Laboratorium } \\
\text { non-TB }\end{array}$ & $\mathrm{n}=1016$ & Kuesioner \\
\hline 2 & Hoffman et al. ${ }^{9}$ & 2016 & $\begin{array}{l}\text { Republik Rakyat } \\
\text { Tiongkok, Iran, } \\
\text { India dan Meksiko }\end{array}$ & KP & Cross-sectional study & $\begin{array}{l}\text { Dokter umum } \\
\text { Dokter spesialis } \\
\text { Perawat } \\
\text { Lainnya }\end{array}$ & $\mathrm{n}=384$ & Kuesioner \\
\hline 3 & Mirtskhulava et al. ${ }^{10}$ & 2016 & Georgia & $\mathrm{K}$ & Cross-sectional study & $\begin{array}{l}\text { Dokter fasilitas } \\
\text { kesehatan sekunder } \\
\text { Perawat } \\
\text { Lainnya }\end{array}$ & $\mathrm{n}=240$ & Kuesioner \\
\hline 4 & Buregyeya et al. ${ }^{14}$ & 2016 & Uganda & KA & Cross-sectional study & $\begin{array}{l}\text { Dokter } \\
\text { Petugas klinis } \\
\text { Perawat } \\
\text { Bidan } \\
\text { Staf lab } \\
\text { Asisten perawat } \\
\text { Lainnya }\end{array}$ & $\mathrm{n}=543$ & Kuesioner \\
\hline 5 & Engelbrecht et al. ${ }^{18}$ & 2016 & Afrika Se-latan & KAP & Cross-sectional study & $\begin{array}{l}\text { Perawat } \\
\text { Asisten perawat } \\
\text { Petugas kesehatan } \\
\text { masyarakat }\end{array}$ & $\mathrm{n}=236$ & Kuesioner \\
\hline 6 & Noé et al..$^{13}$ & 2017 & $\begin{array}{l}\text { Mozambik, Afrika } \\
\text { Timur }\end{array}$ & KAP & Cross-sectional study & $\begin{array}{l}\text { Dokter } \\
\text { Konselor } \\
\text { Perawat } \\
\text { Bidan } \\
\text { Dokter gigi } \\
\text { Dokter Ahli } \\
\text { Mikroskop } \\
\text { Teknisi medis }\end{array}$ & $\mathrm{n}=170$ & Kuesioner \\
\hline 7 & Pardeshi et al. ${ }^{24}$ & 2017 & India & A & Cross-sectional study & $\begin{array}{l}\text { Dokter } \\
\text { Total }\end{array}$ & $\begin{array}{c}\mathrm{n}=305 \\
\mathrm{~N}=5251\end{array}$ & Kuesioner \\
\hline
\end{tabular}




\section{Tabel 1 Daftar Artikel (Lanjutan)}

\begin{tabular}{|c|c|c|c|c|c|c|c|c|}
\hline $\begin{array}{c}\text { No. } \\
\text { Artikel }\end{array}$ & Penulis & $\begin{array}{l}\text { Tahun } \\
\text { Terbit } \\
\end{array}$ & Lokasi Penelitian & Variabel & $\begin{array}{c}\text { Rancangan } \\
\text { Penelitian }\end{array}$ & Responden & $\begin{array}{c}\text { Jumlah } \\
\text { Responden }\end{array}$ & $\begin{array}{c}\text { Instrumen } \\
\text { Penelitian } \\
\end{array}$ \\
\hline 8 & Phetlhu et al. ${ }^{19}$ & 2018 & Afrika Se-latan & $\mathrm{K}$ & Cross-sectional study & $\begin{array}{l}\text { Perawat } \\
\text { Asisten perawat }\end{array}$ & $\mathrm{n}=44$ & Kuesioner \\
\hline 9 & Garcia et al..$^{21}$ & 2018 & Peru & KAP & Cross-sectional study & $\begin{array}{l}\text { Apoteker } \\
\text { Teknisi farmasi }\end{array}$ & $\mathrm{n}=45$ & Kuesioner \\
\hline 10 & Van Rensburg et al. ${ }^{17}$ & 2017 & Afrika Se-latan & KAP & Cross-sectional study & $\begin{array}{l}\text { Perawat } \\
\text { Asisten perawat }\end{array}$ & $\mathrm{n}=202$ & Kuesioner \\
\hline 11 & Ramos et al. ${ }^{11}$ & 2018 & Brazil & KA & Cross-sectional study & $\begin{array}{l}\text { Dokter fasilitas } \\
\text { kesehatan sekunder } \\
\text { Perawat }\end{array}$ & $\mathrm{n}=101$ & Kuesioner \\
\hline 12 & Aadnanes et al. ${ }^{8}$ & 2018 & Norwegia & KAP & Cross-sectional study & $\begin{array}{l}\text { Dokter fasilitas } \\
\text { kesehatan primer }\end{array}$ & $\mathrm{n}=196$ & Kuesioner \\
\hline 13 & Alotaibi et al. ${ }^{15}$ & 2019 & Arab Saudi & KAP & Cross-sectional study & $\begin{array}{l}\text { Dokter fasilitas } \\
\text { kesehatan sekunder } \\
\text { Perawat } \\
\text { Lainnya }\end{array}$ & $\mathrm{n}=540$ & Kuesioner \\
\hline 14 & Alene et al. ${ }^{16}$ & 2019 & Ethiopia & KP & Cross-sectional study & $\begin{array}{l}\text { Dokter fasilitas } \\
\text { kesehatan sekunder } \\
\text { Perawat } \\
\text { Pekerja laboratorium } \\
\text { medis } \\
\text { Lainnya }\end{array}$ & $\mathrm{n}=377$ & Kuesioner \\
\hline 15 & Probandari et al. ${ }^{22}$ & 2019 & Indonesia & KA & Cross-sectional study & $\begin{array}{l}\text { Staf klinis } \\
\text { Staf program TB } \\
\text { Staf lainnya }\end{array}$ & $\mathrm{n}=123$ & Kuesioner \\
\hline 16 & Trajman et al. ${ }^{20}$ & 2019 & Brazil & KAP & Cross-sectional study & $\begin{array}{l}\text { Perawat } \\
\text { Tenaga kesehatan } \\
\text { masyarakat }\end{array}$ & $\mathrm{n}=135$ & Kuesioner \\
\hline \multirow[t]{2}{*}{17} & Ngo et al..$^{12}$ & 2019 & Vietnam & KAP & Cross-sectional study & $\begin{array}{l}\text { Dokter fasilitas } \\
\text { kesehatan sekunder } \\
\text { Perawat } \\
\text { Lainnya }\end{array}$ & $\mathrm{n}=594$ & Kuesioner \\
\hline & & & & & & Total & $\mathrm{N}=5251$ & \\
\hline
\end{tabular}




\begin{tabular}{|c|c|c|c|c|c|c|}
\hline $\begin{array}{l}\text { No. } \\
\text { Artikel }\end{array}$ & Penulis & $\begin{array}{c}\text { Lokasi } \\
\text { Penelitian }\end{array}$ & Responden & Skor Pengetahuan & $\begin{array}{c}\text { Hasil } \\
\text { Pengetahuan }\end{array}$ & Hasil Lainnya \\
\hline 12 & Aadnanes et $a l^{8}$ & Norwegia & $\begin{array}{l}\text { Dokter fasilitas } \\
\text { kesehatan primer }\end{array}$ & $\begin{array}{l}\text { Rata-rata } 8,3 \pm 2,0 \text { dari } \\
\text { skor tertinggi } 14\end{array}$ & Kurang baik & $\begin{array}{l}\text { Kurangnya pengetahuan mengenai } \\
\text { tanda gejala TB dan hanya } 17 \% \\
\text { dokter yang dapat mengidentifikasi } \\
\text { pengobatan standar untuk TB dengan } \\
\text { benar. }\end{array}$ \\
\hline 2 & Hoffman et al. ${ }^{9}$ & $\begin{array}{l}\text { Republik } \\
\text { Rakyat } \\
\text { Tiongkok, } \\
\text { Iran, India dan } \\
\text { Meksiko }\end{array}$ & $\begin{array}{l}\text { Dokter umum, dokter } \\
\text { spesialis, perawat, } \\
\text { dan lainnya }\end{array}$ & NA & Buruk & $\begin{array}{l}\text { Hanya } 11,7 \% \text { responden yang } \\
\text { menjawab dengan benar semua } \\
\text { pertanyaan pengetahuan. }\end{array}$ \\
\hline 3 & Mirtskhulava et al..$^{10}$ & Georgia & $\begin{array}{l}\text { Dokter fasilitas } \\
\text { kesehatan sekunder, } \\
\text { perawat, dan lainnya }\end{array}$ & $\begin{array}{l}\text { Rata-rata skor petugas } \\
\text { kesehatan adalah } 61 \%\end{array}$ & Cukup baik & $\begin{array}{l}\text { Dalam analisis multivariat, dokter } \\
\text { lebih mungkin mengetahui gejala } \\
\text { yang menunjukkan penyakit TB. }\end{array}$ \\
\hline 11 & Ramos et al. ${ }^{11}$ & Brazil & $\begin{array}{l}\text { Dokter fasilitas } \\
\text { kesehatan sekunder, } \\
\text { perawat }\end{array}$ & NA & Kurang baik & $\begin{array}{l}\text { Tidak ada perbedaan yang signifikan } \\
\text { dalam pengetahuan antara dokter dan } \\
\text { perawat. }\end{array}$ \\
\hline 17 & Ngo et al..$^{12}$ & Vietnam & $\begin{array}{l}\text { Dokter fasilitas } \\
\text { kesehatan sekunder, } \\
\text { perawat, dan lainnya }\end{array}$ & $\begin{array}{l}\text { Skor rata-rata } \\
\text { keseluruhan } 7,87 \\
(\mathrm{SD}=1,31) \text { dengan skor } \\
\text { maksimum } 10\end{array}$ & Baik & $\begin{array}{l}\text { Dokter memiliki skor yang } \\
\text { signifikan lebih tinggi dibanding } \\
\text { perawat dan professional kesehatan } \\
\text { lainnya. }\end{array}$ \\
\hline 6 & Noé et al..$^{13}$ & $\begin{array}{l}\text { Mozambik, } \\
\text { Afrika Timur }\end{array}$ & $\begin{array}{l}\text { Dokter, konselor, } \\
\text { perawat, bidan, } \\
\text { dokter gigi, dokter, } \\
\text { ahli mikroskop, } \\
\text { teknisi medis }\end{array}$ & $\begin{array}{l}\text { Rata-rata adalah } 14,89 \\
\text { poin }(\mathrm{SD}=3,61) \text { dari total } \\
\text { kemungkinan } 26 \text { poin }\end{array}$ & Kurang baik & $\begin{array}{l}\text { Dokter memiliki skor pengetahuan } \\
\text { terbesar sedangkan bidan memiliki } \\
\text { skor pengetahuan terendah, dengan } \\
\text { perbedaan signifikan secara statistik } \\
(p=0,02) \text {. }\end{array}$ \\
\hline 4 & Buregyeya et al..$^{14}$ & Uganda & $\begin{array}{l}\text { Dokter, petugas } \\
\text { klinis, perawat, } \\
\text { bidan, staf lab, } \\
\text { asisten perawat, dan } \\
\text { lainnya }\end{array}$ & NA & Baik & $\begin{array}{l}\text { Pada analisis multivariabel, staf } \\
\text { nonklinis, lebih mungkin memiliki } \\
\text { pengetahuan dasar TB yang buruk, } \\
\text { (OR 0,43;95\% CI } 0,27-0,8) \text {. }\end{array}$ \\
\hline 13 & Alotaibi et al..$^{15}$ & Arab Saudi & $\begin{array}{l}\text { Dokter fasilitas } \\
\text { kesehatan sekunder, } \\
\text { perawat, dan lainnya }\end{array}$ & $\begin{array}{l}\text { Skor rata-rata } \\
\text { pengetahuan } 0,52 \\
(\mathrm{SD}=0,17) \text { dengan skor } \\
\text { maksium } 0,900\end{array}$ & Cukup & $\begin{array}{l}\text { Terdapat kesenjangan dalam } \\
\text { pengetahuan TB. } 43-60 \% \text { responden } \\
\text { tidak mengetahui beberapa } \\
\text { gejala umum TB. Dan kurangnya } \\
\text { pengetahuan dalam diagnostik/ } \\
\text { skrining TB. }\end{array}$ \\
\hline
\end{tabular}

Keterangan: $\mathrm{TB}=$ Tuberkulosis; $\mathrm{NA}=$ Not available $; \mathrm{SD}=$ Standar deviasi; $\mathrm{OR}=$ Odds ratio $; \mathrm{CI}=$ Confidence interval; $\mathrm{MDR}-\mathrm{TB}=$ Multidrug resistant tuberculosis $; \mathrm{LTB}=$ Latent 


\section{Tabel 2 Pengetahuan Tenaga Kesehatan (Lanjutan)}

\begin{tabular}{|c|c|c|c|c|c|c|}
\hline $\begin{array}{c}\text { No. } \\
\text { Artikel }\end{array}$ & Penulis & $\begin{array}{c}\text { Lokasi } \\
\text { Penelitian }\end{array}$ & Responden & Skor Pengetahuan & $\begin{array}{c}\text { Hasil } \\
\text { Pengetahuan }\end{array}$ & Hasil Lainnya \\
\hline 14 & Alene et al. ${ }^{16}$ & Ethiopia & $\begin{array}{l}\text { Dokter fasilitas } \\
\text { kesehatan sekunder, } \\
\text { perawat, pekerja } \\
\text { laboratorium medis, } \\
\text { dan lainnya }\end{array}$ & $\begin{array}{l}\text { Skor rata-rata } 7 \text { dengan } \\
\text { skor maksimum } 10\end{array}$ & Kurang baik & $\begin{array}{l}\text { Terdapat kesenjangan dalam } \\
\text { pengetahuan mengenai gejala dan } \\
\text { pengobatan MDR-TB. }\end{array}$ \\
\hline 10 & Van Rensburg et al. ${ }^{17}$ & Afrika Selatan & $\begin{array}{l}\text { Perawat, asisten } \\
\text { perawat }\end{array}$ & NA & Buruk & $\begin{array}{l}\text { Responden mengetahui tanda gejala } \\
\text { TB. Namun, kurangnya pengetahuan } \\
\text { mengenai penularan dan cara } \\
\text { penyebaran TB. }\end{array}$ \\
\hline 5 & Engelbrecht et al. ${ }^{18}$ & Afrika Selatan & $\begin{array}{l}\text { Perawat, asisten } \\
\text { perawat, petugas } \\
\text { kesehatan masyarakat }\end{array}$ & NA & Baik & $\begin{array}{l}\text { Responden dengan tingkat } \\
\text { pengetahuan yang tinggi memiliki } \\
4,029 \text { kali (OR 4,029; } 95 \% \text { CI } \\
1,550 \text { - } 10,469 \text { ) lebih mungkin untuk } \\
\text { memiliki praktik yang baik bila } \\
\text { dibandingkan dengan responden } \\
\text { dengan tingkat pengetahuan yang } \\
\text { buruk. }\end{array}$ \\
\hline 8 & Phetlhu et al. ${ }^{19}$ & Afrika Selatan & $\begin{array}{l}\text { Perawat, asisten } \\
\text { perawat }\end{array}$ & $\begin{array}{l}\text { Skor rata-rata adalah } \\
68 \% \text {, dengan skor } \\
\text { maksimum } 97 \%\end{array}$ & Kurang baik & $\begin{array}{l}\text { Kurangnya pengetahuan mengenai } \\
\text { penemuan kasus TB intensif dan } \\
\text { MDR-TB. }\end{array}$ \\
\hline 16 & Trajman et al. ${ }^{20}$ & Brazil & $\begin{array}{l}\text { Perawat, tenaga } \\
\text { kesehatan masyarakat }\end{array}$ & NA & Kurang baik & $\begin{array}{l}\text { Terdapat kesenjangan mengenai } \\
\text { pentingnya pencegahan TB, } \\
\text { manajemen TB laten (LTBI), } \\
\text { termasuk bagaimana mengenalinya } \\
\text { dan mencegah perkembangan } \\
\text { menjadi TB aktif melalui } \\
\text { pengobatan. }\end{array}$ \\
\hline 9 & Garcia et al..$^{21}$ & Peru & $\begin{array}{l}\text { Apoteker, teknisi } \\
\text { farmasi }\end{array}$ & NA & Baik & $\begin{array}{l}\text { Terdapat kesenjangan dalam } \\
\text { pengetahuan mengenai pencegahan } \\
\text { penularan TB. }\end{array}$ \\
\hline 15 & Probandari et al..$^{22}$ & Indonesia & $\begin{array}{l}\text { Staf klinis, staf } \\
\text { program TB, staf } \\
\text { lainnya }\end{array}$ & NA & Kurang baik & $\begin{array}{l}\text { Kurangnya pengetahuan mengenai } \\
\text { pengendalian infeksi seperti skrining } \\
\text { batuk di antara pengunjung }(38 \%) \\
\text { dan penggunaan masker pernapasan } \\
(48 \%) \text {. }\end{array}$ \\
\hline 1 & Irani et al. $^{23}$ & Iran & $\begin{array}{l}\text { Staf laboratorium } \\
\text { TB, staf laboratorium } \\
\text { non-TB }\end{array}$ & $\begin{array}{l}\text { Skor rata-rata staf } \\
\text { laboratorium TB yaitu } \\
82,6 \text {. Skor rata-rata staf } \\
\text { laboratorium non-TB } \\
\text { yaitu } 69,5 .\end{array}$ & $\begin{array}{l}\text { Pengetahuan staf } \\
\text { laboratorium } \\
\text { TB lebih baik } \\
\text { dibanding } \\
\text { pengetahuan staf } \\
\text { laboratorium } \\
\text { non-TB }\end{array}$ & $\begin{array}{l}\text { Pendidikan memiliki pengaruh yang } \\
\text { siginifikan terhadap pengetahuan. }\end{array}$ \\
\hline
\end{tabular}


Studi di Norwegia menunjukkan bahwa pengetahuan dokter mengenai TB kurang baik; hanya sebanyak $17 \%$ dokter yang dapat mengidentifikasi pengobatan standar untuk TB dengan benar dan kurangnya pengetahuan mengenai tanda gejala TB. ${ }^{8}$ Sejalan dengan studi tersebut, Cina, Iran, India dan Meksiko juga menunjukkan pengetahuan dokter yang buruk; hanya $11,7 \%$ dokter yang menjawab semua pertanyaan pengetahuan dengan benar. ${ }^{9}$

Studi di Georgia menunjukkan dokter lebih mungkin mengetahui gejala TB jika dibandingkan perawat dan tenaga kesehatan lainnya. ${ }^{10}$ Sebuah studi di Brazil menunjukkan dokter memiliki pengetahuan yang lebih baik tentang manajemen efek samping dibanding perawat, namun tidak terdapat perbedaan yang signifikan dalam pengetahuan antara dokter dan perawat. ${ }^{11}$ Skor rata-rata tingkat pengetahuan tenaga kesehatan di Vietnam yakni sebesar 7,87 $(\mathrm{SD}=1,31)$ dengan skor maksimum 10, dan dokter memiliki skor yang signifikan lebih tinggi dibanding tenaga kesehatan lainnya $(\mathrm{p}<0,001) .{ }^{12}$ Di Mozambik, dokter memiliki skor pengetahuan terbesar sedangkan bidan memiliki skor pengetahuan terendah, dengan perbedaan signifikan secara statistik $(\mathrm{p}=0,02) \cdot{ }^{13}$ Pada staf nonklinis lebih mungkin memiliki pengetahuan dasar TB yang buruk (OR 0,43;95\% CI 0,27-0,8). ${ }^{14}$

Tingkat pengetahuan yang baik ditunjukkan oleh tenaga kesehatan yang bekerja selama pelaksanaan haji, namun sebanyak 43-60\% responden tidak mengetahui beberapa gejala umum TB dan memiliki pengetahuan yang kurang baik dalam diagnostik/skrining TB. ${ }^{15}$ Terdapat kesenjangan dalam pengetahuan mengenai gejala dan pengobatan MDR-TB di Ethiopia. ${ }^{16}$ Studi lain menunjukkan bahwa perawat di Afrika Selatan mengetahui gejala $\mathrm{TB}$, namun kurang pengetahuan mengenai penularan dan cara penyebarannya. ${ }^{17}$ Tenaga kesehatan dengan tingkat pengetahuan yang tinggi memiliki 4,029 kali (OR 4,029; 95\% CI 1,550-10,469) lebih mungkin untuk memiliki praktik yang baik. ${ }^{18}$

Pengetahuan perawat mengenai penemuan kasus TB intensif (57\%) dan kasus MDR-TB (67\%) masih tergolong kurang baik. ${ }^{19}$ Begitu pula pengetahuan mengenai TB laten/latent tuberculosis infection (LTBI); masih terdapat kesenjangan tentang pentingnya pencegahan TB, manajemen LTBI: cara mengenalinya dan mencegah perkembangan menjadi TB aktif melalui pengobatan. ${ }^{20}$

Pengetahuan farmasis di Peru cukup baik, namun pengetahuan mengenai pencegahan dan penularan TB masih kurang. ${ }^{21}$ Sebuah studi di Indonesia menunjukkan pengetahuan staf klinis yang kurang dalam hal pengendalian infeksi, seperti skrining batuk di antara pengunjung $(38 \%)$ dan penggunaan masker pernapasan (48\%). ${ }^{22}$ Di Iran, pengetahuan para staf laboratorium TB lebih baik apabila dibandingkan pengetahuan staf laboratorium non-TB, mengingat bahwa tingkat pendidikan memiliki pengaruh yang signifikan terhadap pengetahuan. $^{23}$

\section{Sikap Tenaga Kesahatan terhadap TB}

Secara keseluruhan, sebanyak 7 dari total 13 studi menunjukkan sikap yang positif (Tabel 3). Sikap dokter di India dan Norwegia terhadap penyakit TB menunjukkan hasil yang kurang baik. ${ }^{8,24}$ Di India, 64\% dokter tidak menganggap bahwa TB merupakan ancaman kesehatan utama di negaranya. ${ }^{8}$ Dokter yang pernah mengikuti program pelatihan TB tiga kali lebih mungkin memiliki keinginan untuk membantu pasien TB dibanding mereka yang tidak mengikuti pelatihan tersebut $(\mathrm{OR}=2,95$, 95\% CI (1,33-6,61). ${ }^{24}$ Sebuah studi di Uganda menunjukkan tenaga kesehatan yang tidak mengikuti pelatihan pengendalian infeksi TB secara signifikan dikaitkan dengan efikasi diri yang rendah (aOR 0,52; 95\% CI 0,33-0,81) dan ancaman yang dirasakan rendah untuk terinfeksi TB di tempat kerja (aOR 0,54; 95\% CI $0,36-0,81) .{ }^{14}$ 
Dokter dan perawat di Brazil memiliki sikap yang kurang baik, yakni mereka tidak berpikir bahwa penting untuk menyaring kontak orang dewasa dan anak dengan TB dan LTBI. ${ }^{11}$ Sementara itu, tenaga kesehatan saat pelaksanaan haji menunjukkan sikap yang positif yakni mereka bersedia untuk diskrining TB jika memiliki gejala sugestif, menggunakan alat pelindung diri (APD) saat berurusan dengan pasien TB, tidak akan menunda pengobatan TB jika pasien merasa lebih baik. Namun, 60\% responden tidak mau bekerja di klinik/ bangsal TB. ${ }^{15}$ Pada sikap, tidak ada perbedaan yang signifikan antara grup tenaga kesehatan $(p=0,597) .{ }^{12}$

Sikap negatif ditunjukkan oleh tenaga kesehatan di negara Mozambik dan Afrika Selatan. ${ }^{13,17}$ Adanya stigma di antara tenaga kesehatan terhadap TB menimbulkan sikap yang kurang baik dalam hal perlindungan pada diri sendiri dan orang lain terkait infeksi TB. ${ }^{17}$

Studi lain di Afrika Selatan menunjukkan sikap yang positif, namun sebanyak $31,4 \%$ perawat dan petugas kesehatan masyarakat menyatakan bahwa klinik mereka tidak peduli dengan kesehatan dan keselamatan mereka serta tidak menyediakan sumber daya yang memadai untuk mencegah paparan terhadap TB. Peningkatan sikap meningkatkan praktik 1,090 kali (OR 1,090; 95\% CI 1,016-1,169). ${ }^{18}$

Sikap perawat dan petugas kesehatan masyarakat di Brazil menunjukkan sikap yang positif dengan merasa bahwa penting untuk menyelidiki kontak anak dan orang dewasa untuk LTBI. ${ }^{20}$ Sikap serupa ditunjukkan oleh farmasis di Peru yakni mayoritas menyatakan bahwa mereka suka berbicara mengenai opsi perawatan dan merasa nyaman berbicara mengenai TB dengan klien meraka. ${ }^{21}$ Studi di Indonesia menunjukkan staf klinis program TB dan staf lainnya menyatakan tertekan dan takut dalam melakukan perawatan MDRTB. ${ }^{22}$

Studi di Iran menunjukkan sikap staf laboratorium TB lebih positif dibanding sikap staf laboratorium non-TB. Data menunjukkan bahwa pada staf non-TB, praktik positif terhadap TB 0,10 lebih tinggi per 1-unit peningkatan skor sikap $(\mathrm{p}=0,040){ }^{23}$

\section{Praktik Tenaga Kesehatan terhadap TB}

Pada Tabel 4, dapat dilihat data mengenai praktik tenaga kesehatan terhadap TB. Secara keseluruhan, 5 dari total 11 studi menunjukkan sikap yang positif. Praktik dokter terhadap TB di Norwegia kurang baik, yakni hanya 29\% dokter yang benar dalam mendiagnosis TB aktif yaitu dengan analisis dahak. Sebagian besar dokter tidak memberikan pendidikan kesehatan tentang TB. ${ }^{8}$ Studi lain di Cina, Iran, India, dan Meksiko menunjukkan hanya $3,1 \%$ responden yang memiliki praktik baik. ${ }^{9}$

Petugas kesehatan selama pelaksanaan haji memiliki praktik dalam pencegahan infeksi TB yang baik seperti menjaga kebersihan, menggunakan APD dan melakukan tes dahak ketika mencurigai pasien dengan TB aktif. ${ }^{15}$ Studi di Vietnam juga menunjukkan praktik yang baik; $85 \%$ dokter dan $93,4 \%$ perawat menggunakan masker ketika bertemu dengan pasien. $^{12}$

Tenaga kesehatan di Mozambik, Ethiopia, dan Afrika Selatan menunjukkan praktik yang kurang baik. ${ }^{13,16,17}$ Di Mozambik, hanya sebesar $36,4 \%$ tenaga kesehatan yang dapat mendiagnosis TB dengan benar, sementara sisanya belum tepat dalam mengidentifikasi obat dan menentukan fase perawatan TB. ${ }^{13}$ Hanya 29,17\% tenaga kesehatan di Ethiopia yang menyatakan bahwa mereka mengikuti pedoman ketika memberikan perawatan untuk pasien yang diduga TB atau MDRTB. ${ }^{16}$ Di Afrika Selatan, hanya sebesar 46,0\% perawat yang selalu menggunakan masker N95 selama berinteraksi dengan pasien TB. ${ }^{17}$

Studi lain di Afrika Selatan menunjukkan praktik perawat dan petugas kesehatan masyarakat yang baik, yakni mereka membuka jendela jika mungkin untuk meningkatkan 
Tabel 3 Sikap Tenaga Kesehatan

\begin{tabular}{|c|c|c|c|c|c|c|}
\hline $\begin{array}{c}\text { No. } \\
\text { Artikel } \\
\end{array}$ & Penulis & $\begin{array}{c}\text { Lokasi } \\
\text { Penelitian } \\
\end{array}$ & Responden & Skor Sikap & Hasil Sikap & Hasil Lainnya \\
\hline 12 & Aadnanes et al. ${ }^{8}$ & Norwegia & $\begin{array}{l}\text { Dokter fasilitas } \\
\text { kesehatan primer }\end{array}$ & NA & Negatif & $\begin{array}{l}\text { Mayoritas dokter (64\%) tidak } \\
\text { menganggap TB sebagai ancaman } \\
\text { kesehatan utama di Norwegia. }\end{array}$ \\
\hline 7 & Pardeshi et al. ${ }^{24}$ & India & Dokter & NA & Kurang baik & $\begin{array}{l}\text { Responden yang pernah mengikuti } \\
\text { program pelatihan TB tiga kali lebih } \\
\text { mungkin memiliki keinginan untuk } \\
\text { membantu pasien TB dibandingkan } \\
\text { mereka yang tidak mengikuti pelatihan } \\
\text { tersebut (OR=2,95, } 95 \% \text { CI }(1,33- \\
6,61) \text {. }\end{array}$ \\
\hline 4 & Buregyeya et al..$^{14}$ & Uganda & $\begin{array}{l}\text { Dokter, petugas klinis, } \\
\text { perawat, bidan, staf lab, } \\
\text { asisten perawat, dan } \\
\text { lainnya }\end{array}$ & NA & Positif & $\begin{array}{l}\text { Individu yang tidak menghadiri } \\
\text { pelatihan pengendalian infeksi TB } \\
\text { secara signifikan dikaitkan dengan } \\
\text { efikasi diri yang rendah (aOR } 0,52 \text {; } \\
95 \% \text { CI } 0,33-0,81 \text { ) dan ancaman yang } \\
\text { dirasakan rendah untuk terinfeksi TB } \\
\text { di tempat kerja (aOR } 0,54 ; 95 \% \text { CI } \\
0,36-0,81 \text { ). }\end{array}$ \\
\hline 11 & Ramos et al. ${ }^{11}$ & Brazil & $\begin{array}{l}\text { Dokter fasilitas } \\
\text { kesehatan sekunder, } \\
\text { perawat }\end{array}$ & NA & Kurang baik & $\begin{array}{l}\text { Sebagian besar menyatakan bahwa } \\
\text { mereka tidak berpikir bahwa penting } \\
\text { untuk menyaring kontak orang dewasa } \\
\text { dan anak dengan TBC dan LTBI. }\end{array}$ \\
\hline 13 & Alotaibi et al. ${ }^{15}$ & Arab Saudi & $\begin{array}{l}\text { Dokter fasilitas } \\
\text { kesehatan sekunder, } \\
\text { perawat, dan lainnya }\end{array}$ & $\begin{array}{l}\text { Skor rata-rata } 0,73 \\
(\mathrm{SD}=0,15) \text { dengan } \\
\text { skor maksium } 1\end{array}$ & Positif & $\begin{array}{l}\text { Mayoritas responden bersedia } \\
\text { diskrining TB jika mereka memiliki } \\
\text { gejala sugestif, menggunakan APD } \\
\text { ketika berurusan dengan pasien TB, } \\
\text { tidak akan menunda pengobatan TB } \\
\text { jika pasien merasa lebih baik. }\end{array}$ \\
\hline 17 & Ngo et al. ${ }^{12}$ & Vietnam & $\begin{array}{l}\text { Dokter fasilitas } \\
\text { kesehatan sekunder, } \\
\text { perawat, dan lainnya }\end{array}$ & $\begin{array}{l}\text { Skor rata-rata } \\
\text { keseluruhan } 7,88 \\
(\mathrm{SD}=0,98) \text { dengan } \\
\text { skor maksium } 10\end{array}$ & Positif & $\begin{array}{l}\text { Pada sikap tidak ada perbedaan } \\
\text { yang signifikan antara grup tenaga } \\
\text { kesehatan. }\end{array}$ \\
\hline
\end{tabular}

Keterangan: TB=Tuberkulosis; $\mathrm{NA}=$ Not available; $\mathrm{SD}=$ Standar deviasi; $\mathrm{OR}=$ Odds ratio; $\mathrm{CI}=$ Confidence interval; $\mathrm{APD}=\mathrm{Alat}$ pelindung diri; $\mathrm{MDR}-\mathrm{TB}=$ Multidrug resistant tuberculosis ; LTBI=Latent tuberculosis infection 


\section{Tabel 3 Sikap Tenaga Kesehatan (Lanjutan)}

\begin{tabular}{|c|c|c|c|c|c|c|}
\hline $\begin{array}{c}\text { No. } \\
\text { Artikel }\end{array}$ & Penulis & $\begin{array}{l}\text { Lokasi } \\
\text { Penelitian }\end{array}$ & Responden & Skor Sikap & Hasil Sikap & Hasil Lainnya \\
\hline 6 & Noé et al. ${ }^{13}$ & $\begin{array}{l}\text { Mozambik, } \\
\text { Afrika Timur }\end{array}$ & $\begin{array}{l}\text { Dokter, konselor, } \\
\text { perawat, bidan, dokter } \\
\text { gigi, dokter ahli, } \\
\text { mikroskop, teknisi medis }\end{array}$ & NA & Negatif & Adanya stigma terkait dengan TB. \\
\hline 10 & $\begin{array}{l}\text { Van Rensburg et } \\
\text { al. }{ }^{17}\end{array}$ & Afrika Selatan & Perawat, asisten perawat & NA & Negatif & $\begin{array}{l}\text { Terdapat kesenjangan dalam sikap } \\
\text { terhadap perlindungan pada diri } \\
\text { sendiri dan orang lain terkait infeksi } \\
\text { TB. }\end{array}$ \\
\hline 5 & Engelbrecht et al. ${ }^{18}$ & Afrika Selatan & $\begin{array}{l}\text { Perawat, asisten perawat, } \\
\text { petugas kesehatan } \\
\text { masyarakat }\end{array}$ & $\begin{array}{l}\text { 80,4\% responden } \\
\text { memiliki sikap } \\
\text { positif }\end{array}$ & Positif & $\begin{array}{l}\text { Meskipun sikap positif, } 31,4 \% \\
\text { responden menyatakan bahwa klinik } \\
\text { mereka tidak peduli dengan kesehatan } \\
\text { dan keselamatan mereka dan tidak } \\
\text { menyediakan sumber daya yang } \\
\text { memadai untuk mencegah paparan } \\
\text { terhadap TB. Peningkatan sikap, } \\
\text { meningkatkan praktik } 1,090 \text { kali (OR } \\
\text { 1,090; } 95 \% \text { CI } 1,016-1,169) \text {. }\end{array}$ \\
\hline 16 & Trajman et al. ${ }^{20}$ & Brazil & $\begin{array}{l}\text { Perawat, tenaga } \\
\text { kesehatan masyarakat }\end{array}$ & NA & Positif & $\begin{array}{l}\text { Responden merasa penting untuk } \\
\text { menyelidiki kontak anak dan orang } \\
\text { dewasa untuk LTBI. }\end{array}$ \\
\hline 9 & Garcia et al. ${ }^{21}$ & Peru & Apoteker, teknisi farmasi & NA & Positif & $\begin{array}{l}44,4 \% \text { responden menyatakan bahwa } \\
\text { mereka juga suka berbicara mengenai } \\
\text { opsi perawatan dan } 84,4 \% \text { responden } \\
\text { menyatakan bahwa mereka nyaman } \\
\text { berbicara mengenai TB dengan klien } \\
\text { mereka. }\end{array}$ \\
\hline 15 & Probandari et al..$^{22}$ & Indonesia & $\begin{array}{l}\text { Staf klinis, staf program } \\
\text { TB, staf lainnya }\end{array}$ & NA & Negatif & $\begin{array}{l}\text { Mayoritas responden menyatakan } \\
\text { tertekan dan takut dalam melakukan } \\
\text { perawatan MDR-TB. }\end{array}$ \\
\hline 1 & Irani et al. ${ }^{23}$ & Iran & $\begin{array}{l}\text { Staf laboratorium TB, } \\
\text { staf laboratorium non-TB }\end{array}$ & $\begin{array}{l}\text { Skor rata- } \\
\text { rata sikap staf } \\
\text { laboratorium TB } \\
\text { yaitu } 87,6 \text {. Skor } \\
\text { rata-rata sikap staf } \\
\text { laboratorium non- } \\
\text { TB yaitu } 50,7\end{array}$ & $\begin{array}{c}\text { Sikap staf } \\
\text { laboratorium } \\
\text { TB lebih positif } \\
\text { dibanding sikap } \\
\text { staf laboratorium } \\
\text { non-TB }\end{array}$ & $\begin{array}{l}\text { Pada staf non-TB, praktik positif } \\
\text { terhadap TB } 0,10 \text { lebih tinggi per } \\
\text { 1-unit peningkatan skor sikap } \\
(p=0,040) .\end{array}$ \\
\hline
\end{tabular}
tuberculosis ; LTBI=Latent tuberculosis infection 


\section{Tabel 4 Praktik Tenaga Kesehatan}

\begin{tabular}{|c|c|c|c|c|c|c|}
\hline $\begin{array}{c}\text { No } \\
\text { Artikel }\end{array}$ & Penulis & $\begin{array}{c}\text { Lokasi } \\
\text { Penelitian }\end{array}$ & Responden & Skor Praktik & Hasil Praktik & Hasil Lainnya \\
\hline 12 & Aadnanes et al. ${ }^{8}$ & Norwegia & $\begin{array}{l}\text { Dokter fasilitas } \\
\text { kesehatan primer }\end{array}$ & NA & Kurang baik & $\begin{array}{l}\text { Hanya } 29 \% \text { dokter yang benar dalam } \\
\text { mendiagnosis TB aktif yaitu dengan } \\
\text { analisis dahak. }\end{array}$ \\
\hline 2 & Hoffman et al. ${ }^{9}$ & $\begin{array}{l}\text { Republik } \\
\text { Rakyat } \\
\text { Tiongkok, } \\
\text { Iran, India dan } \\
\text { Meksiko }\end{array}$ & $\begin{array}{l}\text { Dokter umum, } \\
\text { dokter spesialis, } \\
\text { perawat, dan lainnya }\end{array}$ & NA & Buruk & $\begin{array}{l}\text { Hanya } 3,1 \% \text { responden yang memiliki } \\
\text { praktik baik. }\end{array}$ \\
\hline 13 & Alotaibi et al. ${ }^{15}$ & Arab Saudi & $\begin{array}{l}\text { Dokter fasilitas } \\
\text { kesehatan sekunder, } \\
\text { perawat, dan lainnya }\end{array}$ & $\begin{array}{l}\text { Skor rata-rata } 0,81 \\
(\mathrm{SD}=0,17) \text { dengan } \\
\text { skor maksium } 1\end{array}$ & Baik & $\begin{array}{l}\text { Praktik yang baik dalam pencegahan } \\
\text { infeksi TB seperti menjaga kebersihan, } \\
\text { menggunakan APD dan melakukan tes } \\
\text { dahak ketika mencurigai pasien dengan TB } \\
\text { aktif. }\end{array}$ \\
\hline 17 & Ngo et al. ${ }^{12}$ & Vietnam & $\begin{array}{l}\text { Dokter fasilitas } \\
\text { kesehatan sekunder, } \\
\text { perawat, dan lainnya }\end{array}$ & $\begin{array}{c}\text { Skor rata-rata } \\
\text { keseluruhan } 7,08 \\
(\mathrm{SD}=1,96) \text { dengan } \\
\text { skor maksimum } 10\end{array}$ & Baik & $\begin{array}{l}85 \% \text { dokter dan } 93,4 \% \text { perawat } \\
\text { menggunakan masker ketika bertemu } \\
\text { dengan pasien. }\end{array}$ \\
\hline 6 & Noé et al..$^{13}$ & $\begin{array}{l}\text { Mozambik, } \\
\text { Afrika Timur }\end{array}$ & $\begin{array}{l}\text { Dokter, konselor, } \\
\text { perawat, bidan, } \\
\text { dokter gigi, dokter } \\
\text { ahli mikroskop, } \\
\text { teknisi medis }\end{array}$ & $\begin{array}{c}\text { Skor rata-rata } 3,2 \\
\text { dari } 9(35,6 \% \\
\quad \mathrm{SD}=2,44)\end{array}$ & Kurang baik & $\begin{array}{l}\text { Hanya } 36,4 \% \text { yang dapat mendiagnosis } \mathrm{TB} \\
\text { dengan benar, dan banyak responden yang } \\
\text { masih belum tepat dalam mengidentifikasi } \\
\text { obat dan menentukan fase perawatan TB. }\end{array}$ \\
\hline 14 & Alene et al. ${ }^{16}$ & Ethiopia & $\begin{array}{l}\text { Dokter fasilitas } \\
\text { kesehatan sekunder, } \\
\text { perawat, pekerja } \\
\text { laboratorium medis, } \\
\text { dan lainnya }\end{array}$ & $\begin{array}{l}\text { Skor rata-rata } \\
4 \text { dari } 7 \text {, hanya } \\
19,6 \% \text { responden } \\
\text { yang memiliki } \\
\text { praktik baik }\end{array}$ & Buruk & $\begin{array}{l}\text { Terdapat kesenjangan dalam praktik, } \\
\text { dimana hanya } 29,17 \% \text { responden yang } \\
\text { menyatakan bahwa mereka mengikuti } \\
\text { pedoman ketika memberikan perawatan } \\
\text { untuk pasien yang diduga TB atau MDR- } \\
\text { TB. }\end{array}$ \\
\hline
\end{tabular}




\section{Tabel 4 Praktik Tenaga Kesehatan (Lanjutan)}

\begin{tabular}{|c|c|c|c|c|c|c|}
\hline $\begin{array}{c}\text { No } \\
\text { Artikel }\end{array}$ & Penulis & $\begin{array}{c}\text { Lokasi } \\
\text { Penelitian }\end{array}$ & Responden & Skor Praktik & Hasil Praktik & Hasil Lainnya \\
\hline 10 & $\begin{array}{l}\text { Van Rensburg et } \\
\text { al. } .^{17}\end{array}$ & Afrika Selatan & $\begin{array}{l}\text { Perawat, asisten } \\
\text { perawat }\end{array}$ & NA & Buruk & $\begin{array}{l}\text { Terdapat kesenjangan dalam praktik } \\
\text { terhadap perlindungan pada diri sendiri dan } \\
\text { orang lain terkait infeksi TB, seperti hanya } \\
46,0 \% \text { perawat yang selalu menggunakan } \\
\text { masker N95 selama berinteraksi dengan } \\
\text { pasien TB. }\end{array}$ \\
\hline 5 & Engelbrecht et al. ${ }^{18}$ & Afrika Selatan & $\begin{array}{l}\text { Perawat, asisten } \\
\text { perawat, petugas } \\
\text { kesehatan } \\
\text { masyarakat }\end{array}$ & $\begin{array}{l}72,9 \% \text { responden } \\
\text { memiliki praktik } \\
\text { yang baik }\end{array}$ & Baik & $\begin{array}{l}\text { Praktik yang baik dimana } 95,2 \% \text { responden } \\
\text { membuka jendela jika mungkin untuk } \\
\text { meningkatkan ventilasi alami dan } 91,8 \% \\
\text { menjelaskan kepada pasien mengapa } \\
\text { penting untuk membuka jendela. }\end{array}$ \\
\hline 16 & Trajman et al. ${ }^{20}$ & Brazil & $\begin{array}{l}\text { Perawat, tenaga } \\
\text { kesehatan } \\
\text { masyarakat }\end{array}$ & NA & Cukup baik & $\begin{array}{l}\text { Praktik responden cukup baik terutama } \\
\text { mengenai efek samping rejimen TB aktif, } \\
\text { yang juga mengandung isoniazid. }\end{array}$ \\
\hline 9 & Garcia et al. ${ }^{21}$ & Peru & $\begin{array}{l}\text { Apoteker, teknisi } \\
\text { farmasi }\end{array}$ & NA & Baik & $\begin{array}{l}\text { Responden yang biasanya melihat pasien } \\
\text { dengan gejala pernapasan seperti batuk } \\
\text { lebih dari } 2 \text { minggu merekomendasikan } \\
\text { untuk perawatan ke pusat kesehatan. }\end{array}$ \\
\hline 1 & Irani et al..$^{23}$ & Iran & $\begin{array}{l}\text { Staf laboratorium } \\
\text { TB, staf } \\
\text { laboratorium non- } \\
\text { TB }\end{array}$ & $\begin{array}{l}\text { Skor rata-rata staf } \\
\text { laboratorium TB } \\
\text { 57,9. skor rata-rata } \\
\text { staf laboratorium } \\
\text { non TB } 40,82\end{array}$ & Sama-sama buruk & $\begin{array}{l}\text { Praktik pada staf TB } 0,64 \text { lebih tinggi } \\
\text { dengan peningkatan } 1 \text { unit dalam skor } \\
\text { pengetahuan }(\mathrm{p}<0,001) \text {. Pada staf non-TB, } \\
\text { praktik positif terhadap TB } 0,08 \text { lebih tinggi } \\
\text { per } 1 \text {-unit peningkatan skor pengetahuan } \\
(\mathrm{p}<0,001) \text {, dan } 0,10 \text { lebih tinggi per } 1 \text {-unit } \\
\text { peningkatan skor sikap }(\mathrm{p}=0,040)\end{array}$ \\
\hline
\end{tabular}


ventilasi alami dan menjelaskan kepada pasien alasan mengenai pentingnya untuk membuka jendela. ${ }^{18}$ Sebuah studi di Brazil terhadap perawat dan petugas kesehatan masyarakat menunjukkan praktik yang baik terutama mengenai efek samping rejimen TB aktif, yang juga mengandung isoniazid. ${ }^{20}$ Studi lain di Peru juga menunjukkan praktik yang baik, yakni farmasis yang biasanya melihat pasien dengan gejala pernapasan seperti batuk lebih dari dua minggu merekomendasikan untuk perawatan ke pusat kesehatan. ${ }^{21}$ Studi lainnya di Iran menunjukkan praktik staf laboratorium TB dan staf laboratorium non-TB samasama buruk, praktik pada staf TB 0,64 lebih tinggi dengan peningkatan 1 unit dalam skor pengetahuan $(\mathrm{p}<0,001)$. Pada staf non-TB, praktik positif terhadap TB 0,08 lebih tinggi per1-unit peningkatan skor pengetahuan $(p<0,001)$, dan 0,10 lebih tinggi per 1-unit peningkatan skor sikap $(\mathrm{p}=0,040){ }^{23}$

\section{Upaya untuk Meningkatkan Pengetahuan, Sikap dan Praktik Tenaga Kesehatan terhadap TB}

Secara keseluruhan, 9 dari 16 studi memiliki tingkat pengetahuan yang buruk, 6 dari 13 studi memiliki sikap negatif, dan 6 dari 11 studi memiliki praktik yang buruk. Hasil tersebut secara keseluruhan dinilai masih kurang baik. Salah satu cara untuk meningkatkan pengetahuan, sikap dan praktik yakni dengan melalui pendidikan dan pelatihan. Penelitian di Iran menunjukkan adanya korelasi tingkat pendidikan dengan pengetahuan. ${ }^{23}$ Studi di Mozambik menunjukkan tingkat pendidikan dikaitkan dengan skor praktik yang lebih baik. ${ }^{13}$ Studi di Norwegia dan Ethiopia menunjukkan tingkat pengetahuan TB yang baik dikaitkan dengan mengikuti pelatihan mengenai TB. ${ }^{8} 16$ Studi di Afrika Selatan menunjukkan pelatihan memiliki pengaruh yang signifikan secara statistik terhadap sikap positif dalam pencegahan TB. ${ }^{17}$

\section{Simpulan}

Artikel ini merangkum 17 studi observasi mengenai pengetahuan, sikap dan praktik mengenai TB di antara tenaga kesehatan di negara Asia, Afrika, Eropa dan Amerika yang dipublikasi dari tahun 2015-2020. Studi ini menilai pengetahuan, sikap dan praktik tenaga kesehatan mengenai TB, dengan jenis studi cross-setional dan menggunakan instrumen penelitian berupa kuesioner. Ukuran sampel berkisar dari 44 hingga 1.016 responden. Hasilnya menunjukkan bahwa masih terdapat kesenjangan dalam pengetahuan, sikap dan praktik di antara tenaga kesehatan mengenai TB. Upaya peningkatan pengetahuan, sikap dan praktik tenaga kesehatan dapat dilakukan dengan meningkatkan tingkat pendidikan. Selain itu juga dengan melakukan pelatihan terkait TB, baik pencegahan infeksi TB, pelatihan terkait MDR-TB dan pengendalian infeksi TB bagi tenaga kesehatan.

\section{Pendanaan}

Penulis tidak memperoleh dana dari sumber manapun dalam penelitian ataupun penulisan artikel ini.

\section{Konflik Kepentingan}

Seluruh penulis menyatakan tidak terdapat potensi konflik kepentingan dengan penelitian, kepenulisan (authorship), dan atau publikasi artikel ini.

\section{Daftar Pustaka}

1. World Health Organization. The top 10 causes of death. Geneva: World Health Organization; 2018.

2. World Health Organization. Global tuberculosis report. Geneva: World Health Organization; 2019.

3. Kementerian Kesehatan Republik 
Indonesia. Pedoman nasional pengendalian tuberkulosis. Kementerian Kesehatan Republik Indonesia. Jakarta: Kementerian Kesehatan Republik Indonesia; 2011.

4. Tudor C, Van Walt M Der, Margot B, Dorman SE, Pan WK, Yenokyan G, et al. Tuberculosis among health care workers in KwaZulu-Natal, South Africa: A retrospective cohort analysis. BMC Public Health. 2014;14(1):891. doi: 10.1186/147 1-2458-14-891

5. World Health Organization. Transforming and scaling up health professionals' education and training. Geneva: World Health Organization; 2013.

6. World Health Organization. Guideline for the prevention of tuberculosis in health care facilities in resource-limited settings. Geneva: World Health Organization; 1999.

7. Mushtaq MU, Majrooh MA, Ahmad W, Rizwan M, Luqman MQ, Aslam MJ, et al. Knowledge, attitudes and practices regarding tuberculosis in two districts of Punjab, Pakistan. Int J Tuberc Lung Dis. 2010;14(3):303-10.

8. Aadnanes O, Wallis S, Harstad I. A cross-sectional survey of the knowledge, attitudes and practices regarding tuberculosis among general practitioners working in municipalities with and without asylum centres in eastern Norway. BMC Health Serv Res. 2018;18(1):987. doi: 10.1186/s12913-018-3792-4

9. Hoffman SJ, Guindon GE, Lavis JN, Randhawa H, Becerra-Posada F, Dejman $\mathrm{M}$, et al. Surveying the knowledge and practices of health professionals in China, India, Iran, and Mexico on treating tuberculosis. Am J Trop Med Hyg. 2016; 94(5):959-70. doi: 10.4269/ajtmh.15-05 38

10. Mirtskhulava V, Whitaker JA, Kipiani M, Harris DA, Tabagari N, Owen-Smith AA, et al. Determinants of tuberculosis infection control related behaviors among healthcare workers in the country of Georgia. Infect Control Hosp Epidemiol. 2015;36(5):522-8. doi: 10.1017/ice.2015.5

11. Ramos J, Wakoff-Pereira MF, CordeiroSantos M, de Albuquerque M de FM, Hill PC, Menzies D, et al. Knowledge and perceptions of tuberculosis transmission and prevention among physicians and nurses in three Brazilian capitals with high incidence of tuberculosis. J Bras Pneumol. 2018;44(2):168-70. doi: 10.15 90/S1806-37562018000000019

12. Ngo CQ, Manabe T, Vu G Van, Chu HT, Vu TTT, Tran TT, et al. Difficulties in tuberculosis infection control in a general hospital of Vietnam: A knowledge, attitude, and practice survey and screening for latent tuberculosis infection among health professionals. BMC Infect Dis. 2019;19(1):951. doi: 10.1186/s12879-01 9-4593-Z

13. Noé A, Ribeiro RM, Anselmo R, Maixenchs M, Sitole L, Munguambe K, et al. Knowledge, attitudes and practices regarding tuberculosis care among health workers in Southern Mozambique. BMC Pulm Med 2017;17(1):2. doi: 10.1186/s1 2890-016-0344-8

14. Buregyeya E, Kasasa S, Mitchell EMH. Tuberculosis infection control knowledge and attitudes among health workers in Uganda: A cross-sectional study. BMC Infect Dis. 2016;16(1):416. doi: 10.1186/ s12879-016-1740-7

15. Alotaibi B, Yassin Y, Mushi A, Maashi F, ThomasA, MohamedG, etal. Tuberculosis knowledge, attitude and practice among healthcare workers during the 2016 Hajj. PLoS One. 2019;14(1):e0210913. doi: 10. 1371/journal.pone.0210913

16. Alene KA, Adane AA, Yifiru S, Bitew BD, Adane A, Koye DN. Knowledge and practice of health workers about control and prevention of multidrugresistant tuberculosis in referral hospitals, 
Ethiopia: A cross-sectional study. BMJ Open. 2019;9(2):1-8. doi: 10.1136/bmjo pen-2018-022948

17. van Rensburg AJ, Engelbrecht $M$, Kigozi G, van Rensburg D. Tuberculosis prevention knowledge, attitudes, and practices of primary health care nurses. Int J Nurs Pract. 2018;24(6):e12681. doi: 10.1111/ijn. 12681

18. Engelbrecht M, Janse van Rensburg A, Kigozi G, van Rensburg HCJD. Factors associated with good TB infection control practices among primary healthcare workers in the Free State Province, South Africa. BMC Infect Dis. 2016;16(1):633. doi: 10.1186/s12879-016-1984-2

19. Phetlhu DR, Bimerew M, Marie-Modeste RR, Naidoo M, Igumbor J. Nurses' knowledge of tuberculosis, HIV, and integrated HIV/TB care policies in rural Western Cape, South Africa. J Assoc Nurses AIDS Care. 2018;29(6):876-86. doi: 10.1016/j.jana.2018.05.008

20. Trajman A, Wakoff-Pereira MF, RamosSilva J, Cordeiro-Santos M, Militaõ de Albuquerque MDF, Hill PC, et al. Knowledge, attitudes and practices on tuberculosis transmission and prevention among auxiliary healthcare professionals in three Brazilian high-burden cities: A cross-sectional survey. BMC Health
Serv Res. 2019;19(1):532. doi: 10.1186/s 12913-019-4231-x

21. García PJ, Hernández-Córdova G, Pourjavaheri P, Gómez-Paredes HJ, Sudar S, Bayer AM. Knowledge, attitudes and practices related to tuberculosis in pharmacy workers in a cross-sectional survey in El Agustino, Peru. PLoS One. 2018;13(7):e0196648. doi: 10.1371/journ al.pone. 0196648

22. Probandari A, Sanjoto H, Mahanani MR, Azizatunnisa L, Widayati S. Being safe, feeling safe, and stigmatizing attitude among primary health care staff in providing multidrug-resistant tuberculosis care in Bantul District, Yogyakarta Province, Indonesia. Hum Resour Health. 2019;17(1):16. doi: 10.1186/s12960-0190354-8

23. Irani AD, Shahraki AH, Ghaderi E, Nasehi M, Mostafavi E. Lack of optimum practice among health care workers regarding tuberculosis in Iran: A knowledge, attitude, and practice study. Am J Infect Control. 2015;43(5):e7-12. doi: 10.1016/j.ajic.20 15.01.020

24. Pardeshi GS, Kadam D, Chandanwale A, Bollinger R, Deluca A. Resident doctors' attitudes toward tuberculosis patients. Indian J Tuberc. 2017;64(2):89-92. doi: 10.1016/j.ijtb.2016.11.001 